\title{
Dietary Plant Extracts Combined with Vitamin E Limit the Discoloration in Stored n-3 PUFA Rich Meat
}

\author{
Mylène Delosière1, Emilie Parafita², Mihaela Habeanu ${ }^{3}$, Dominique Gruffat ${ }^{1}$, Denys Durand1 \\ ${ }^{1}$ Université Clermont Auvergne, INRA, VetAgro Sup, UMR1213 Herbivores, Clermont-Ferrand, France \\ ${ }^{2} \mathrm{ADIV}$, Association pour le Développement de l'Institut des Viandes, Clermont-Ferrand, France \\ ${ }^{3}$ IBNA, National Research Development Institute for Animal Biology and Nutrition, Balotesti, Romania \\ Email: denis.durand@inra.fr
}

How to cite this paper: Delosière, M., Parafita, E., Habeanu, M., Gruffat, D. and Durand, D. (2018) Dietary Plant Extracts Combined with Vitamin E Limit the Discoloration in Stored n-3 PUFA Rich Meat. Agricultural Sciences, 9, 23-36. https://doi.org/10.4236/as.2018.91003

Received: November 21, 2017

Accepted: January 6, 2018

Published: January 9, 2018

Copyright $\odot 2018$ by authors and Scientific Research Publishing Inc. This work is licensed under the Creative Commons Attribution-NonCommercial International License (CC BY-NC 4.0).

http://creativecommons.org/licenses/by-nc/4.0/ (c) (i) (8) Open Access

\begin{abstract}
In finishing cull-cows given n-3 PUFA-rich diets (for $101 \pm 3$ days preceding slaughter), the ability of vitamin E ( $2.8 \mathrm{~g} / \mathrm{animal} /$ day $)$ or vitamin $\mathrm{E}$ associated with plant extracts rich in polyphenols (PERP) (126 g/animal/day) to limit discoloration was evaluated on color attributes of Longissimus thoracis (LT) and Semitendinosus (ST) processed meat. Color attributes were determined after muscles ageing and retail display in different packaging systems consisting in $14 \mathrm{~d}$. under vacuum $(\mathrm{V}), 4 \mathrm{~d}$. aerobic $(\mathrm{A})$ or $7 \mathrm{~d}$. under modified atmosphere (70:30, $\left.\mathrm{O}_{2} / \mathrm{CO}_{2}\right)(\mathrm{MA})$. Vit. E associated with PERP were able to limit color deterioration by decreasing metmyoglobin\% in ST and LT for all tested packaging systems. The antioxidant association increased the $L^{\star}$ coordinate and the oxygenation index as compared with vit. E alone. We show the possibility to limit color deterioration of processed beef by an original dietary antioxidant strategy during the finishing period.
\end{abstract}

\section{Keywords \\ Color, Vitamin E, Plant, Beef, Packaging}

\section{Practical Application}

Dietary n-3 PUFA associated to vitamin E and plant extract rich in polyphenols could be added in the feeding of cull-cows during the finishing period in order to improve their meat quality. By the antioxidant strategy, PUFA rich beef could be conserved from color discoloration. 


\section{Introduction}

During the finishing period, ruminant intake of an appropriated quantity of extruded linseed rich in linolenic acid (LA, 18:3 n-3) increased deposition in muscle tissues of LA and n-3 long chain PUFA improving the nutritional meat value [1]. Nevertheless, these nutritional manipulations of meats increased susceptibility to lipid oxidation since n-3 PUFA act as substrates that promote the oxidative process [2]. Final products of lipid oxidation are correlated with myoglobin oxidation into metmyoglobin [3]. For consumer color is an indicator of freshness and wholesomeness [4] and meat purchasing decisions are influenced by color, which is related to myoglobin status. Consequently, brown color linked to metmyoglobin formation must be limited to preserve beef retail appearance. During retail period, normal and high oxygen atmospheres are commonly used to preserve the beef bright red color and to reduce microbial growth [5] [6]. Thus, the gas mixture usually used for modified atmosphere packaged beef is $20 \%-30 \%$ $\mathrm{CO}_{2}$ and $70 \%-80 \% \mathrm{O}_{2}$ [6] leading to a longer storage period (up to $7 \mathrm{~d}$. in practice) than the aerobic packaging $\left(4 \mathrm{~d}\right.$.) containing only $20 \% \mathrm{O}_{2}$. However, although high concentration of oxygen in packaging limits color deterioration in meat, this might favor rancidity associated to lipid oxidation [5] and therefore favor apparition of oxidation products at low concentrations. Recently, we shown that lipid oxidation occurs in n-3 PUFA rich meats at the end of retail period in aerobic $\left(4 \mathrm{~d}\right.$.) and under modified atmosphere $\left(70 / 30 ; \mathrm{O}_{2}: \mathrm{CO}_{2}\right)(7 \mathrm{~d}$.) packaging systems [7].

In order to limit deleterious effects of lipid oxidation, antioxidant sources, such as vitamin E (vit. E) are commonly used [8]. When incorporated into the diets of producing bovines, vit. E (as dl- $\alpha$-tocopheryl acetate) can effectively control directly lipid oxidation and indirectly color deterioration [8] [9] [10]. Although the effect of dietary vit. $\mathrm{E}$ on lipid oxidation and discoloration in meat was assessed in different ways [11] [12] [13], its preventive effect was much less studied on PUFA rich meats except in one study on calf muscles using very low amount of synthetic vitamin E (4 g/animal/d) [14]. Nevertheless, high vit. E doses do not prevent effectively lipid oxidation in case of tissues of animals given PUFA rich diets such as rats [15], sheep [16] and beef [14]. In this context, new dietary antioxidants given with vit. E were tested in our laboratory for preventing lipid oxidation and discoloration in beef. A dietary mixture of vit. E associated with not purified plant extracts rich in polyphenols (PERP) prepared from rosemary (Rosemarinus officinalis), grape (Vinis vitifera), citrus (Citrus paradisi) and marigold (Calendula officinalis) (collaboration with Phytosynthèse Company, Riom, 63, patent \#P170-B-23.495FR) was effective to protect animals from deleterious consequences of lipid oxidation as reported in the plasma of rat and sheep [15] [16], finishing cows [17] and dairy cows [18] and on processed meat from cull cows [7]. The PERP mixture is of known concentration, controlled and reproducible. By using the same samples from this study on cull cows [7], we investigate here the effect of the association of vit. E with PERP added in 
the n-3 PUFA rich diet of cows on meat color attributes of LT and ST muscles after ageing and retail storage in aerobic, vacuum and modified atmosphere packaging systems.

\section{Materials and Methods}

\subsection{Animals and Diets}

Experimental procedures and animal holding facilities had respected French animal protection legislation, including licensing of experimenters. They were controlled and approved by the French Veterinary Services (slaughterhouse and cattle experimental facilities license numbers are \#63 34501 and \#63 345.17, respectively). The experiment was conducted on 15 Normand cull cows, of which meat is frequently consumed in France. Animals were selected on live weight (649 $\pm 41 \mathrm{~kg})$, age (48 - 60 month-old) and body fat score $(2.0 \pm 0.3)$ estimated by visual and manual procedures. Cows were randomly assigned to three isoenergetic and isonitrogenous diets ( $\mathrm{n}=5$ per diet) during a $101 \pm 3 \mathrm{~d}$. of finishing period. The basal diet consisted in straw (30\%) and concentrate (70\%); the concentrate was supplemented with $40 \mathrm{~g}$ of lipids/kg DM obtained from extruded linseeds (60\%) and rapeseeds (40\%). Animals were given either 1) the basal diet (C group, $\mathrm{n}=5$ ), or 2) the basal diet supplemented with vit. E as dl- $\alpha$-tocopheryl acetate (INZO Company, Château-Thierry, France), at the maximal dose used in practice (155 IU/kg diet DM; $2.8 \mathrm{~g} / \mathrm{animal} / \mathrm{d})(\mathrm{E}$ group, $\mathrm{n}=5$ ) or 3$)$ the basal diet supplemented with vit. $\mathrm{E}$ and the PERP mixture (Phytosynthèse Company, Riom, France) (7 g/kg diet DM; $126 \mathrm{~g} / \mathrm{animal} / \mathrm{d}$ ) (EP group, $\mathrm{n}=5$ ). Cows were kept in groups of 4 in straw bedded pens in a single naturally ventilated shed. Pens were equipped with electronically controlled feeding gates randomly attributed to a feeding condition. Cows were equipped with an individual electronic transponder mounted on a collar opening only the defined feed gate. They received twice daily the concentrate-based diet and straw, adjusted for a target growth rate of $1150 \mathrm{~g} /$ day.

\subsection{Samples and Packaging Treatments}

At the end of the finishing period, cows were slaughtered at the INRA experimental slaughterhouse (Saint-Genès-Champanelle, 63122, France). Carcasses were refrigerated at $4^{\circ} \mathrm{C}$ for $24 \mathrm{~h}$. Longissimus thoracis (LT) and Semitendinosus (ST) muscles from the right half carcass were removed, vacuum packed and stored for ageing at $4^{\circ} \mathrm{C}$ for $10 \mathrm{~d}$. (vacuum ageing). The left half carcass was whole-aged at $4^{\circ} \mathrm{C}$ for $10 \mathrm{~d}$. (ageing in carcass). Both muscles were cut into $10-15$ $\mathrm{mm}$ (LT) and $8-10 \mathrm{~mm}$ (ST) thick steaks corresponding to the type commonly found on the French market realized by the Association for Meat Institute Development (ADIV, 63000 Clermont-Ferrand, France). Meat samples were stored at $4^{\circ} \mathrm{C}$ under a standard supermarket fluorescent light. A first sample was placed in an expanded polystyrene (PSE) tray type 049405 (Boulegon-Parry, France) overwrapped in an aerobic vinyl stretchable film $9 \mu \mathrm{m}$ thick (Soussana, France) 
for $4 \mathrm{~d}$. (A). A second sample was placed in a polystyrene (EVOH) tray type 2450 (Form'plast, France) and packed under $70 \% \mathrm{O}_{2} / 30 \% \mathrm{CO}_{2}$ with a Multivac T200 using OPP-T504 AF/20/30 film $52 \mu \mathrm{m}$ thick (Soussana, France) for $7 \mathrm{~d}$. (MA). The packaging gas was provided by Linde-gas (France). Finally, the last sample was placed under vacuum with a Multivac C400 in a bag type 102353 (Boulegon-parry, France) for $14 \mathrm{~d}$. (V). Just after the storage period, samples were used to determine color attributes.

\subsection{Instrumental Measurement of Color}

Surface color measurements were performed after a $4 \mathrm{~d}$. (A), a $7 \mathrm{~d}$. (MA) and a $14 \mathrm{~d}$. (V) storage period. Color measurements were realized immediately after opening of each pack in order to maintain the effects of the specific gas composition (A or MA). Visible reflectance spectra (from 360 to $760 \mathrm{~nm}$ ) were determined with an UVIKON 933 spectrophotometer. Color coordinates were calculated in the CIE-L*a*b* system (1976) according to the method of [19].

\subsection{Determination of Meat Metmyoglobin and Oxygenation Index}

The relative metmyoglobin at the surface of meat after $4 \mathrm{~d}$. (A), $7 \mathrm{~d}$. (MA) and $14 \mathrm{~d}$. (V) storage was measured by spectrophotometry as described by [19], which allows the proportions of met-, oxy- and myoglobin fractions forms to be calculated. Reflectance at 473, 525, 572, 580, 630 and $730 \mathrm{~nm}$ wavelengths were measured using UV-V is spectrophotometer. According to the mathematical method of [19], metmyoglobin\% of total pigment in meat was calculated by using 1395-((R572-R730)/(R525-R730)) equation and oxygenation index by R630-R580 calculation.

\subsection{Statistical Analysis}

Mean values of meat were calculated by using the STATISTICA software Version 12 (DELL, Texas, USA, 2015). Data were analyzed by an ANOVA fitting diet, muscle, ageing and packaging conditions and their interactions as fixed effects. Whatever the diet or the muscle type, no significant differences were observed on tested values between under vacuum or in half carcass meat ageing. Color deterioration of stored beef was not influenced by the two ageing methods tested, which agreed with our previous evaluation of lipid oxidation intensity showing no differences between the two ageing conditions [7]. Consequently, ageing effect was not considered in the model. Color coordinate $b^{\star}$ was not analyzed, because the dataset did not follow a normal distribution. The fixed effects (diet, muscle and packaging) were calculated based on 10 samples repetitions.

\section{Results and Discussion}

\subsection{Meat Color Characterization}

Meat visual appreciation was carried out by evaluation of different parameters. 
In our study, average of $\mathrm{L}^{*}$ value from processed LT in C group (Table 1(a)) was 37.7, which was slightly higher than $\mathrm{L}^{\star}$ value of 30.6 determined for LT muscle just after slaughter in Normand cows by [20] corresponding to a dark red meat. In this study the processing period could have increased meat lightness, since full bloom, based upon low lightness $\mathrm{L}^{*}$, occurs immediately after the muscle went into rigor mortis [21].

In the CIE Lab system, positive $\mathrm{a}^{\star}$ value is associated to meat redness. Here, $\mathrm{a}^{*}$ values from retailed meats stayed under 21 (Table 1(b)). According to [21], the maximum redness of muscles from Normand cows amounted to 25.7 just after slaughter. The redness slight decrease observed in our samples resulted probably from the meat ageing and packaging exposing meat to air and light [6]. Moreover, cows of this study were relatively fat with a higher body score condition at

Table 1. Means of $\mathrm{L}^{\star}$ coordinate (a) and $\mathrm{a}^{*}$ coordinate (b) of meat from Longissimus thoracis (LT) and Semitendinosus (ST) muscles. Data were determined after 1) $14 \mathrm{~d}$. in a tray under vacuum packaging $(\mathrm{V}, \mathrm{n}=10)$, or for 2) $4 \mathrm{~d}$. aerobic packaging $(\mathrm{A}, \mathrm{n}=10)$, or for 3) $7 \mathrm{~d}$. under modified atmosphere packaging $\left(70: 30, \mathrm{O}_{2} / \mathrm{CO}_{2}\right)(\mathrm{MA}, \mathrm{n}=10)$ following $12 \mathrm{~d}$. ageing. During the $101 \mathrm{~d}$. finishing period, cows were fed a concentrate/ straw-based diet (70:30) supplemented with PUFA from extruded linseed and rapeseed (40 $\mathrm{g}$ oil $/ \mathrm{kg}$ DM) (C) or the same diet enriched with vitamin E (155 IU/kg diet DM) (E) or with vitamin $\mathrm{E}$ and plant extracts rich in polyphenols $(7 \mathrm{~g} / \mathrm{kg}$ diet DM) (EP).

(a)

\begin{tabular}{cccccccc}
\hline Muscle & Packaging & C & E & EP & SEM & Statistical effects & P values \\
\hline ST & V & 37.57 & 36.61 & 39.82 & 0.55 & Diet & 0.02 \\
& A & 40.8 & 38.42 & 39.64 & 0.40 & Packaging & 0.05 \\
& MA & 39.58 & 40.1 & 40.65 & 0.18 & Muscle & $<0.0001$ \\
LT & V & 33.42 & 33.14 & 34.42 & 0.22 & Interactions & NS \\
& A & 34.99 & 34.33 & 34.82 & 0.11 & & \\
& MA & 35.83 & 32.1 & 37.29 & 0.89 & & \\
& Means & $37.03^{\mathrm{ab}}$ & $35.78^{\mathrm{a}}$ & $37.77^{\mathrm{b}}$ & & & \\
& & & & & & &
\end{tabular}

(b)

\begin{tabular}{cccccccc}
\hline Muscle & Packaging & C & E & EP & SEM & Statistical effects & P values \\
\hline ST & V & 17.78 & 14.18 & 16.67 & 0.61 & Diet & NS \\
& A & 18.71 & 18.2 & 19.27 & 0.18 & Interactions & $<0.05$ \\
& MA & 16.53 & 15.79 & 17.47 & 0.28 & & \\
LT & V & 17.76 & 14.68 & 17.09 & 0.54 & & \\
& A & 18.19 & 20.84 & 20.22 & 0.46 & & \\
& MA & 18.23 & 21.96 & 18.65 & 0.68 & & \\
& Means & 17.87 & 17.61 & 18.23 & & & \\
& & & & & & \\
\end{tabular}

Significant differences $(P<0.05)$ between LT and ST muscles were reported in the results and discussion section. Means values reported at the bottom of the table are the means of the corresponding column (all the packaging and muscle conditions in a same diet). ${ }^{a-b}$ Means bearing different superscripts are significantly different at $P<0.05$ and highlight the diet effect. NS $=$ not significant. 
slaughter than standard Normand cows (on average 3.5 vs. 3.0). By this way, fatty meat could exhibit slightly different color values than standard meats. The two colors represented by $b^{*}$ (blue and yellow) are not typical or intuitively related to beef color. Nevertheless, $\mathrm{b}^{*}$ coordinate was more correlated to the brown color as described by sensory panelists than to the sensory evaluation of blue and yellow descriptors [22]. Unfortunately, $b^{\star}$ data set did not follow a normal distribution and was not analyzed by ANOVA procedure.

The oxygenation index (R630-R580) represents the bright red meat impression and the jury's preference for a meat [20]. As previously reported by [12], the mean value of the oxygenation index obtained in our study was 15.2 (Table 2).

For meat metmyoglobin percentage, the mean value from the LT and ST muscles in the C group (30.6\%) (Table 3) was higher than $22.3 \%$ reported by [12], but close to $29.2 \%$ reported by [23]. Such differences can be explained by the different muscle type or ageing duration twice lower in the [12] study. In our cows given PUFA rich diets, meat color differed from that of steers used in the two other reported studies. This could be in relation with the fatty composition of muscle or the effect of terminal lipid oxidation products on the myoglobin stability. Yin and Faustman [24] showed an increase of heme and lipid oxidation with the increase of FA unsaturation. In the same way, [25] reported that 4-hydroxy-2-nonenal (a by-product of 18:2 n-6 peroxidation) induces a redox instability of oxymyoglobin present in cattle skeletal muscle via its adduction to

Table 2. Means of the oxygenation index $\left(\mathrm{R}_{630}-\mathrm{R}_{580}\right)$ of meat from Longissimus thoracis (LT) and Semitendinosus (ST) muscles. Data were determined after 1) $14 \mathrm{~d}$. in a tray under vacuum packaging $(\mathrm{V}, \mathrm{n}=10)$, or for 2) $4 \mathrm{~d}$. aerobic packaging $(\mathrm{A}, \mathrm{n}=10)$, or for 3) 7 d. under modified atmosphere packaging $\left(70: 30, \mathrm{O}_{2} / \mathrm{CO}_{2}\right)(\mathrm{MA}, \mathrm{n}=10)$ following $12 \mathrm{~d}$. of ageing in carcass or under vacuum. During the $101 \mathrm{~d}$. finishing period, cows were fed a concentrate/straw-based diet (70:30) supplemented with PUFA from extruded linseed and rapeseed (40 g oil $/ \mathrm{kg} \mathrm{DM})(\mathrm{C})$ or the same diet enriched with vitamin E (155 IU/kg diet $\mathrm{DM})(\mathrm{E})$ or with vitamin $\mathrm{E}$ and plant extracts rich in polyphenols (7 $\mathrm{g} / \mathrm{kg} \operatorname{diet} \mathrm{DM})$ (EP).

\begin{tabular}{cccccccc}
\hline Muscle & Packaging & C & E & EP & SEM & Statistical effects & P values \\
\hline ST & V & 17.46 & 12.88 & 17.94 & 0.93 & Diet & 0.01 \\
& A & 17.77 & 16.83 & 18.18 & 0.23 & Packaging & NS \\
LT & MA & 14.86 & 13.76 & 17.3 & 0.60 & Muscle & $<0.0001$ \\
& V & 14.56 & 12.23 & 14.33 & 0.43 & Interactions & NS \\
& MA & 12.78 & 15.16 & 15.24 & 0.56 & & \\
& Means & $15.11^{\mathrm{ab}}$ & $14.30^{\mathrm{a}}$ & $16.33^{\mathrm{b}}$ & & & \\
\hline
\end{tabular}

Significant differences $(P<0.05)$ between LT and ST muscles were reported in the results and discussion section. Means values reported at the bottom of the table are the means of the corresponding column (all the packaging and muscle conditions in a same diet). ${ }^{\mathrm{a}-\mathrm{b}}$ Means bearing different superscripts are significantly different at $P<0.05$ and highlight the diet effect. NS = not significant. 
Table 3. Means of the metmyoglobin percentage present in meat from Longissimus thoracis $(\mathrm{LT})$ and Semitendinosus (ST) muscles. Data were determined after 1) $14 \mathrm{~d}$. in a tray under vacuum packaging $(\mathrm{V}, \mathrm{n}=10)$, or for 2$) 4 \mathrm{~d}$. aerobic packaging $(\mathrm{A}, \mathrm{n}=10)$, or for 3) $7 \mathrm{~d}$. under modified atmosphere packaging $\left(70: 30, \mathrm{O}_{2} / \mathrm{CO}_{2}\right)(\mathrm{MA}, \mathrm{n}=10)$ following 12 d. ageing. During the $101 \mathrm{~d}$. finishing period, cows were fed a concentrate/straw-based diet (70:30) supplemented with PUFA from extruded linseed and rapeseed (40 g oil/kg $\mathrm{DM})(\mathrm{C})$ or the same diet enriched with vitamin E (155 IU/kg diet DM) (E) or with vitamin $\mathrm{E}$ and plant extracts rich in polyphenols $(7 \mathrm{~g} / \mathrm{kg}$ diet DM) (EP).

\begin{tabular}{cccccccc}
\hline Muscle & Packaging & C & E & EP & SEM & Statistical effects & $P$ values \\
\hline ST & V & 28.28 & 30.9 & 26.27 & 0.77 & Diet & 0.002 \\
& A & 29.61 & 31.62 & 29.12 & 0.44 & Packaging & $<0.0001$ \\
& MA & 31.65 & 33.52 & 27.89 & 0.96 & Muscle & NS \\
LT & V & 29.44 & 28.42 & 29.4 & 0.19 & Diet x Muscle & 0.002 \\
& A & 32.33 & 30.84 & 30.48 & 0.33 & Other interactions & NS \\
& MA & 32.39 & 31.46 & 30.75 & 0.27 & & \\
& Means & $30.62^{\mathrm{a}}$ & $31.13^{\mathrm{a}}$ & $28.99^{\mathrm{b}}$ & & &
\end{tabular}

Significant differences $(P<0.05)$ between LT and ST muscles were reported in the results and discussion section. Means values reported at the bottom of the table are the means of the corresponding column (all the packaging and muscle conditions in a same diet). ${ }^{a-b}$ Means bearing different superscripts are significantly different at $P<0.05$ and highlight the diet effect. NS $=$ not significant.

histidine residues. Consequently, meat samples rich in n-3 PUFA were more susceptible to lipid oxidation [7] and could be more susceptible to myoglobin oxidation and consequently had less stable color than meats from no PUFA supplemented cattle. Metmyoglobin values from our experimentation stayed relatively close to that reported in the literature. These values are in acceptable limits, since meats containing $40 \%$ metmyoglobin or more are downgraded or rejected for purchase [6].

\subsection{Effect of Muscle}

Mean $\mathrm{L}^{*}$ value from ST was $12 \%$ higher $(\mathrm{P}<0.05)$ than $\mathrm{LT}$ muscle in $\mathrm{C}$ group (Table 1(a)). Moreover, oxygenated index from ST was $11 \%$ higher $(\mathrm{P}<0.05)$ than that of LT muscle (Table 2). In contrast, no significant muscle effect was observed for metmyoglobin percentage (Table 3). Each muscle has an inherent biochemistry and hence varied in their biochemical and color attributes [26] [27]. Differences could be attributed to differences in composition (collagen content or lipid composition) or in fiber types between these muscles.

\subsection{Effect of Meat Packaging Treatments}

In the $\mathrm{C}$ group, mean $\mathrm{L}^{*}$ values from retailed meats (Table $1(\mathrm{a})$ ) were $17 \%$ higher than value obtained at slaughter by [21], but largely under threshold of tolerance for red meat which is of about 50 to 55 [20]. So, our beef can be considered as very acceptable for consumers. The significant packaging effect on $L^{*}$ value was not clear regarding data evolution. The $\mathrm{a}^{\star}$ values showed no signifi- 
cant differences between the different packaging systems. High levels of $\mathrm{O}_{2}$ were known to support oxymyoglobin formation [22] and therefore to promote lipid oxidation, which can eventually adversely affect color especially in animals given PUFA rich diet such as in the present study. However, no significant color differences between V, A and MA packaging were observed (Table 1(b) and Table 2). Metmyoglobin percentages in beef under $\mathrm{V}$ was $7 \%$ and $9 \%$ lower than that in A and MA packaging, respectively $(P<0.05)$ (Table 3$)$, probably in relation with the absence of $\mathrm{O}_{2}$ [28]. Meat under $\mathrm{V}$, having purple color, seemed to be better protected against discoloration than that in A and MA packs. These observations were in accordance with results obtained on lipid oxidation measured on the same samples [7] showing a higher antioxidant status of meat after retail storage in V vs. A and MA packaging systems. This provides evidence that under vacuum meats were better protected against lipid oxidation and color deterioration than meats in contact with oxygen. A and MA packed meats were more susceptible to lipid oxidation [7] associated to a slight deterioration of color, according to metmyoglobin percentages (Table 3). A meat protection must be provided against these two deteriorative reactions in these packaging systems.

\subsection{Effect of Dietary Vitamin E Supplementation}

In the present study, the studied variables indicated no improvement of color stability of PUFA rich meat by vit. E. In cows from E group (given $2.3 \mathrm{~g}$ $\alpha$-tocopherol/animal/d for the finishing period) $\alpha$-tocopherol content in processed beef amounted $4.2 \mu \mathrm{g} / \mathrm{g}$ fresh tissue, which was 2.6 times higher than beef from the control group (means between ST and LT muscles) [7]. This data and those of the present study were in agreement with data from [12] study on steers given $1 \mathrm{~g}$ vit E/animal/d with a mean $\alpha$-tocopherol content in processed beef (from longissimus lumborum and triceps brachii) of $5.3 \mu \mathrm{g} / \mathrm{g}$ (1.4-fold higher than in control animals) but without any significant improvement of color parameters ( $\mathrm{a}^{\star}, \mathrm{R} 630-\mathrm{R} 580$, MetMb percentage). Nevertheless, several studies reported that vit. E is able to delay beef color deterioration [8] [9] [10]. [11] reported that vit. E content must be about $3.5 \mu \mathrm{g} / \mathrm{g}$ to assure a good retail of beef from animals without lipid supplement. In the present study, beef vit. E content was higher than this threshold, but did not provide any effective protection against meat color deterioration. This could be explained by the higher beef $n-3$ PUFA content increasing risk of lipid oxidation and color degradation, these two reactions being interrelated [29] [30] [31]. [11] reported that dietary vit. E (2 $\mathrm{g} / \mathrm{kg}$ diet) can protect stored beef against lipid oxidation and color deterioration simultaneously from no lipid supplemented animals. Currently, vit. E is able to protect meat from lipid oxidation, with its color-stabilizing effect indirectly by delaying oxymyoglobin oxidation through the inhibition of lipid oxidation [29]. However, vit. E alone was not enough effective to limit lipid oxidation intensity in all stored meats from n-3 PUFA supplemented animals [7]. These results might explain the lack of protective effect of vit. E towards color deterioration in 
the present study.

Increasing vit. E level in the diet would be a recommended strategy to limit both meat lipid oxidation and color deterioration. However, an excess of vit. $\mathrm{E}$ will be catabolized or excreted [32]. In human, high dietary vit. E doses did not improve protection and moreover could have an adverse effect by increasing mortality [33]. Indeed, it had been reported that high $\alpha$-tocopherol concentration would increase in vitro mitochondrial $\mathrm{O}_{2}$ consumption [34]. This effect would increase production of reactive oxygen species (ROS) from mitochondria in aqueous phase [35] involving higher risks of lipid oxidation and consequently, a possible decrease of myoglobin stability. In case of n-3 PUFA rich diets, vit. E was not sufficient to effectively limit lipid oxidation and color deterioration in stored beef and a high $\alpha$-tocopherol supplementation of cattle could have deleterious effects. Thus, other antioxidants such as hydrosoluble polyphenols would be necessary to reinforce the vit. E protective action.

\subsection{Effect of Vit. E Associated with PERP}

$\mathrm{L}^{*}$ coordinates (Table $\left.1(\mathrm{a})\right)$ were $6 \%$ higher $(P<0.01)$ in meats from the EP group when compared to $\mathrm{E}$ group. Values stayed in common standards for retail beef. Redness $\left(\mathrm{a}^{*}\right)$ (Table $1(\mathrm{~b})$ ) was not altered by dietary PERP. The oxygenation index (Table 2 ) for all tested packaging systems was $14 \%$ higher $(P<0.05)$ in beef from the EP group as compared to E group indicating a better meat oxygenation (redness recovery) in these steaks, that could be attractive for consumers. In all packaging systems (V, A and MA), PERP with vit. E were able to significantly protect meats towards discoloration as regarding metmyoglobin percentage $(-7 \%, P<0.05)$ (Table 3$)$ when compared to values from $\mathrm{C}$ group, whereas vit. E alone was not $(+7.5 \%, \mathrm{NS})$. We previously demonstrated that similar doses of vit. E + PERP effectively protected PUFA rich beef against lipid oxidation as shown by meat malondialdehyde (MDA) concentrations systematically lower than $0.8 \mu \mathrm{g} / \mathrm{g}$ tissue in all stored meats [7]. Consequently, this antioxidant mixture was able to stabilize beef color from PUFA rich beef by limiting lipid oxidation, as already proposed for vit. E in standard meats [29]. We calculated the correlation between MDA content from PUFA rich meat from ST muscle stored under modified atmosphere packaging, which represent the most deleterious conditions regarding lipid oxidation [7] (Figure 1). MDA concentration explained $26.6 \%$ of metmyoglobin percentage variability. Reactions of myoglobin with other lipid oxidation products, such as hydroxyalkenals (4-hydroxy-2-nonenal (4-HNE) and 4-hydroxy-2-hexenal (4-HHE)), could explained a resting part of variability in the formation of metmyoglobin via oxidation [25]. The later in vitro study suggested that 4-HNE accelerates oxidation of oxymyoglobin in bovine skeletal muscle by covalent connection with histidine residues. It was hypothesized that histidine 64 residue by 4 -HNE could alter the oxymyoglobin structure around the heme cleft and subsequently impact the redox stability. Recently, [36] reported that hydroxyalkenals, final products of n-3 PUFA 


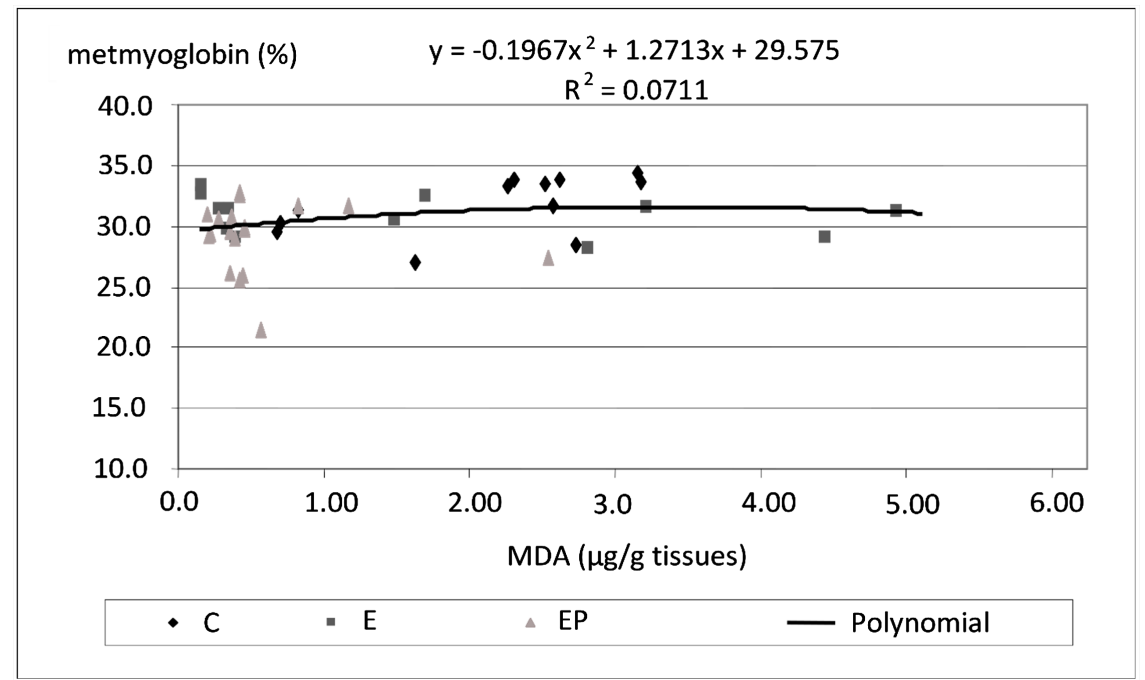

Figure 1. Relationship between malondialdehyde (MDA) concentrations ( $\mu \mathrm{g} / \mathrm{g}$ tissues) and metmyoglobin percentage (\%) in Semitendinosus muscle packaging under modified atmosphere (MA). The curve is based on a polynomial correlation function.

(4-HHE) and n-6 PUFA (4-HNE) peroxidation, are strongly reactive. Generated in the hydrophobic part of cells, hydroxyalkenals would disperse within the cells and attack distant targets in other compartments, such as hydrophilic part of cell. Oxymyoglobin, located in the hydrophilic phase of muscle cells, could be attacked by $4-\mathrm{HHE}$ and 4-HNE, which react readily with nucleophilic molecules such as thiols and amines. We hypothesized that the antioxidant association of PERP with vit. E would limit meat lipid oxidation intensity by limiting the formation of these aldehydes and consequently could have a protective action on red oxymyoglobin towards effect induced by covalent linkages. PERP activity could also limit the myoglobin oxidation by direct ROS uptake in the aqueous phases. Indeed, it is well known that polyphenols such as those of the PERP mix could be present at the aqueous/lipid interface [37], near to the hydrophilic myoglobin. By this way, they would limit lipid oxidation and oxidation of myoglobin by the capture of ROS produced in aqueous phases.

\section{Conclusion}

In this study, the association of dietary natural antioxidants (PERP) and vit. $\mathrm{E}$ was effective to limit discoloration in stored n-3 PUFA rich meat. Both antioxidant sources would act by complementary mechanisms of action, limiting lipid oxidation (as shown previously in [7]) and consequently discoloration. The protection of both sensorial and nutritional qualities of processed beef rich in PUFA was possible by an original dietary antioxidant strategy in animal feeding.

\section{Acknowledgements}

This work was funded by the LIPIVIMUS integrated program financed by the French National Research Agency. We thank the Phytosynthese Company 
(Riom, France) for providing the original antioxidant mixture of plant extracts rich in polyphenol (patent \#P170-B-23.495 FR), and the experimental installations and abattoir of INRA Auvergne-Rhône-Alpes (Clermont-Ferrand/Theix) for animal rearing and slaughtering. We also address specific thanks to Anne-Sophie Bage, Céline Chantelauze, Françoise Duboisset, Christiane Legay, Marinette Martinaud and Agnès Thomas for their skilled technical assistance.

\section{Conflict of Interest}

Authors declare no conflict of interest.

\section{Author Contributions}

M. Delosière participated to design the study, led experimentation, collected data, interpreted the results, conducted statistical analysis, drafted and finalized the manuscript.

D. Durand designed the study, led experimentation, interpreted the results and drafted the manuscript.

D. Gruffat participated to design the study and draft the manuscript.

M. Habeanu collected data and participate to leading experimentation.

E. Parafita collected data and participate to leading experimentation.

\section{References}

[1] Bauchart, D., Gladine, C., Gruffat, D., Leloutre, L. and Durand, D. (2005) Effects of Diets Supplemented with Oil Seeds and Vitamin E on Specific Fatty Acids of Rectus Abdominis Muscle in Charolais Fattening Bulls. In: Hocquette, J.F. and Gigli, S., Eds., Indicators of Milk and Beef Quality, EAAP Publication, Slovenia, 431-436.

[2] Durand, D., Scislowski, V., Gruffat, D., Chilliard, Y. and Bauchart, D. (2005) High-Fat Rations and Lipid Peroxidation in Ruminants Consequences on the Health of Animals and Quality of Their Products. In: Hocquette, J.F. and Gigli, S., Eds., Indicators of Milk and Beef Quality, EAAP Publication, Slovenia, 137-150.

[3] Faustman, C., Cassens, R.G., Schaefer, D.M., Buege, D.R., Williams, S.N. and Scheller, K.K. (1989) Improvement of Pigment and Lipid Stability in Holstein Steer Beef by Dietary Supplementation With Vitamin-E. Journal of Food Science, 54, 858-862.

[4] Mancini, R.A. and Hunt, M.C. (2005) Current Research in Meat Color. Meat Science, 71, 100-121. https://doi.org/10.1016/j.meatsci.2005.03.003

[5] Lund, M.N., Hviid, M.S. and Skibsted, L.H. (2007) The Combined Effect of Antioxidants and Modified Atmosphere Packaging on Protein and Lipid Oxidation in Beef Patties During Chill Storage. Meat Science, 76, 226-233.

https://doi.org/10.1016/j.meatsci.2006.11.003

[6] Mcmillin, K.W. (2008) Where Is Map Going? A Review and Future Potential of Modified Atmosphere Packaging for Meat. Meat Science, 80, 43-65. https://doi.org/10.1016/j.meatsci.2008.05.028

[7] Gobert, M., Gruffat, D., Habeanu, M., Parafita, E., Bauchart, D. and Durand, D. (2010) Plant Extracts Combined with Vitamin E in PUFA-Rich Diet of Cull Cows Protect Processed Beef against Lipid Oxidation. Meat Science, 85, 676-683. https://doi.org/10.1016/j.meatsci.2010.03.024 
[8] Arnold, R.N., Scheller, K.K., Arp, S.C., Williams, S.N. and Schaefer, D.M. (1993) Dietary Alpha-Tocopheryl Acetate Enhances Beef Quality in Holstein and Beef Breed Steers. Journal of Food Science, 58, 28-33.

[9] Faustman, C. and Wang, K. (2000) Potential Mechanisms by Which Vitamin E Improves Oxidative Stability of Myoglobin. In: Decker, E.A., Faustman, C. and Lopez-Bote, C.J., Eds., Antioxidants in Muscle Foods: Nutritional Strategies to Improve Quality, John Wiley \& Sons, Hoboken, NJ, 135-152.

[10] Kerry, J.P., Buckley, D.J. and Morrissey, P.A. (2000) Improvement of Oxidative Stability of Beef and Lamb with Vitamin E. In: Decker, E.A., Faustman, C. and Lopez-Bote, C.J., Eds., Antioxidants in Muscle Foods: Nutritional Strategies to Improve Quality, John Wiley \& Sons, Hoboken, NJ, 229-261.

[11] Lynch, M.P., Kerry, J.P., Buckley, D.J., Faustman, C. and Morrissey, P.A. (1999) Effect of Dietary Vitamin E Supplementation on the Color and Lipid Stability of Fresh, Frozen and Vacuum-Packaged Beef. Meat Science, 52, 95-99. https://doi.org/10.1016/S0309-1740(98)00153-3

[12] Gatellier, P., Hamelin, C., Durand, Y. and Renerre, M. (2001) Effect of a Dietary Vitamin E Supplementation on Color Stability and Lipid Oxidation of Air- and Modified Atmosphere-Packaged Beef. Meat Science, 59, 133-140. https://doi.org/10.1016/S0309-1740(01)00063-8

[13] Sales, J. and Koukolova V. (2014) Dietary vitamin E and Lipid and Color Stability of Beef and Pork: Modeling of Relationships. Journal of Animal Sciences, 89, 2836-2848. https://doi.org/10.2527/jas.2010-3335

[14] Granit, R., Angel, S., Akiri, B., Holzer, Z., Aharoni, Y., Orlov, A. and Kanner, J. (2001) Effects of Vitamin E Supplementation on Lipid Peroxidation and Color Retention of Salted Calf Muscle From a Diet Rich in Polyunsaturated Fatty Acids. Journal of Agricultural and Food Chemistry, 49, 5951-5956. https://doi.org/10.1021/jf010459s

[15] Gladine, C., Morand, C., Rock, E., Gruffat, D., Bauchart, D. and Durand, D. (2007) The Antioxidative Effect of Plant Extracts Rich in Polyphenols Differs between Liver and Muscle Tissues in Rats Fed n-3 PUFA Rich Diets. Animal Feed Science and Technology, 139, 257-272. https://doi.org/10.1016/j.anifeedsci.2007.01.015

[16] Gladine, C., Morand, C., Rock, E., Bauchart, D. and Durand, D. (2007) Plant Extracts Rich in Polyphenols (PERP) Are Efficient Antioxidants to Prevent Lipoperoxidation in Plasma Lipids from Animals Fed n-3 PUFA Supplemented Diets. Animal Feed Science and Technology, 136, 281-296. https://doi.org/10.1016/j.anifeedsci.2006.09.003

[17] Gobert, M., Bauchart, D., Bonnefoy, J.C., Faure, P. and Durand, D. (2008) L'apport d'extraits végétaux riches en polyphénols associé à de la vitamine E protège efficacement les vaches recevant des rations riches en AGPI n-3 de la lipoperoxydation plasmatique. 15èmes Journées Rencontres Recherches Ruminants, Paris, 3-4 Décembre 2008, 124.

[18] Gobert, M., Martin, B., Ferlay, A., Chilliard, Y., Graulet, B., Pradel, P., Bauchart, D. and Durand, D. (2009) Plant Polyphenols Associated with Vitamin E Can Reduce Plasma Lipoperoxidation in Dairy Cows Given n-3 Polyunsaturated Fatty Acids. Journal of Dairy Science, 92, 6095-6104. https://doi.org/10.3168/jds.2009-2087

[19] Krzywicki, K. (1979) Assessment of Relative Content of Myoglobin, Oxymyoglobin and Metmyoglobin at the Surface of Beef. Meat Science, 3, 1-10.

https://doi.org/10.1016/0309-1740(79)90019-6 
[20] Moëvi, I. (2006) Le point sur ... la couleur de la viande. Interbev \& Institut de l'Elevage, $113 \mathrm{p}$.

[21] Young, O.A., Priolo, A., Simmons, N.J. and West, J. (1999) Effects of Rigor Attainment Temperature on Meat Blooming and Color on Display. Meat Science, 52, 47-56. https://doi.org/10.1016/S0309-1740(98)00147-8

[22] O’sullivan, A., Galvin, K., Moloney, A.P., Troy, D.J., O’sullivan, K. and Kerry, J.P. (2003) Effect of Pre-Slaughter Rations of Forage and/or Concentrates on the Composition and Quality of Retail Packaged Beef. Meat Science, 63, 279-286. https://doi.org/10.1016/S0309-1740(02)00082-7

[23] Muramoto, T., Nakanishi, N., Shibata, M. and Aikawa, K. (2003) Effect of Dietary Beta-Carotene Supplementation on Beef Color Stability during Display of Two Muscles from Japanese Black Steers. Meat Science, 63, 39-42. https://doi.org/10.1016/S0309-1740(02)00050-5

[24] Yin, M.C. and Faustman, C. (1993) Influence of Temperature, pH, and Phospholipidd-Composition upon the Stability of Myoglibin and Phospholipid-A Liposome Model. Journal of Agricultural and Food Chemistry, 41, 853-857. https://doi.org/10.1021/jf00030a002

[25] Alderton, A.L., Faustman, C., Liebler, D.C. and Hill, D.W. (2003) Induction of Redox Instability of Bovine Myoglobin by Adduction with 4-Hydroxy-2-Nonenal. Biochemistry, 42, 4398-4405. https://doi.org/10.1021/bi0271695

[26] Renerre, M. (2006) La mesure de la couleur de la viande. Proceedings des 11èmes Journées Sciences du Muscle et Technologie de la Viande, Clermont-Ferrand, 4-5 Octobre 2006, 257-258.

[27] Jurie, C., Picard, B., Hocquette, J.F., Dransfield, E., Micol, D. and Listrat, A. (2007) Muscle and Meat Quality Characteristics of Holstein and Salers Cull Cows. Meat Science, 77, 459-466. https://doi.org/10.1016/j.meatsci.2007.04.014

[28] Faustman, C. and Cassens, R.G. (1990) Influence of Aerobic Metmyoglobin Reducing Capacity on Color Stability of Beef. Journal of Food Science, 55, 1278-1279. https://doi.org/10.1111/j.1365-2621.1990.tb03915.x

[29] Faustman, C., Chan, W.K.M., Schaefer, D.M. and Havens, A. (1998) Beef Color Update: The Role for Vitamin E. Journal of Animal Science, 76, 1019-1026. https://doi.org/10.2527/1998.7641019x

[30] Faustman, C., Liebler, D.C., Mcclure, T.D. and Sun, Q. (1999) Alpha, Beta-Unsaturated Aldehydes Accelerate Oxymyoglobin Oxidation. Journal of Agricultural and Food Chemistry, 47, 3140-3144. https://doi.org/10.1021/jf990016c

[31] O’grady, M.N., Monahan, F.J. and Brunton, N.P. (2001) Oxymyoglobin Oxidation and Lipid Oxidation in Bovine Muscle-Mechanistic Studies. Journal of Food Science, 66, 386-392. https://doi.org/10.1111/j.1365-2621.2001.tb16115.x

[32] Aurousseau, B. (2002) Oxygen Radicals in Farm Animals. Physiological Effects and Consequences on Animal Products. Inra Productions Animales, 15, 67-82.

[33] Pearson, P., Lewis, S.A., Britton, J., Young, I.S. and Fogarty, A. (2006) The Pro-Oxidant Activity of High-Dose Vitamin E Supplements in Vivo. BioDrugs, 20, 271-273. https://doi.org/10.2165/00063030-200620050-00002

[34] Tang, J.L., Faustman, C., Hoagland, T.A., Mancini, R.A., Seyfert, M. and Hunt, M.C. (2005) Interactions between Mitochondrial Lipid Oxidation and Oxymyoglobin Oxidation and the Effects of Vitamin E. Journal of Agricultural and Food Chemistry, 53, 6073-6079. https://doi.org/10.1021/jf0501037 
[35] Favier, A. (2003) Le stress oxydant: Intérêt conceptuel et expérimental dans la compréhension des mécanismes des maladies et potentiel thérapeutique. L'actualité chimique novembre-décembre, 269-270 \& 108-115.

[36] Catala, A. (2009) Lipid Peroxidation of Membrane Phospholipids Generates Hydroxy-Alkenals and Oxidized Phospholipids Active in Physiological and/or Pathological Conditions. Chemistry and Physics of Lipids, 157, 1-11. https://doi.org/10.1016/j.chemphyslip.2008.09.004

[37] Manach, C., Scalbert, A., Morand, C., Remesy, C. and Jimenez, L. (2004) Polyphenols: Food Sources and Bioavailability. The American Journal of Clinical Nutrition, 79, 727-747. 